\title{
ROUGHNESS, RESIDUAL STRESSES AND PITTING CORROSION EFFECT ON SHOT PEENED AA 7075
}

\author{
Sebastjan Žagar, Janez Grum
}

Original scientific paper

The paper deals with the effect of roughness, residual stresses and pitting corrosion on different shot peened (SP) ENAW 7075 aluminium alloy in different states. Suitable residual stress profile increases the applicability and life cycle of mechanical parts, treated by shot peening. Pitting corrosion has a major influence on aging of structural elements made of high strength aluminium alloys as corrosion pits lead to earlier fatigue crack initiation under tensile dynamic loading. In order to improve material resistance to corrosion fatigue it is necessary to reduce pit-tip stresses. To eliminate or reduce pit stresses, shot peening was proposed. The objective of the research was to establish the optimal parameters of the shot peening treatment of the aluminium alloy in different precipitation hardened states with regard to residual stress profiles and corrosion resistance. The analysis indicated that particles such as $\mathrm{Al}_{7} \mathrm{Cu}_{2} \mathrm{Fe}$ and $\mathrm{MgZn}_{2}$ play an important role in pitting corrosion and after SP the number and size of surface pits was reduced.

Keywords: aluminium alloy; corrosion resistance; pitting corrosion; residual stresses; roughness; shot peening

Hrapavost, zaostala naprezanja i točkasta korozija na sačmarenom AA 7075

Izvorni znanstveni članak

Rad analizira učinak hrapavosti, zaostalih naprezanja i točkaste korozije na sačmarenoj ENAW 7075 aluminijskoj leguri u različitim stanjima Odgovarajući profil zaostalog naprezanja povećava primjenljivost i trajnost mehaničkih dijelova, podvrgnutih sačmarenju. Točkasta korozija uvelike utječe na starenje konstrukcijskih elemenata izrađenih od aluminijskih legura visoke čvrstoće budući da rupice nastale korozijom dovode do ranijeg stvaranja pukotina zbog zamora materijala pod vlačnim dinamičkim opterećenjem. U svrhu poboljšanja otpornosti materijala na zamor zbog korozije, potrebno je smanjiti naprezanja na rubove pukotina. Da bi se otklonila ili smanjila ta naprezanja, predloženo je sačmarenje. Cilj je istraživanja bio pronaći optimalne parametre sačmarenja aluminijske legure u raznim stanjima precipitacijskog otvrdnjavanja u odnosu na profile zaostalog naprezanja i otpornost na koroziju. Analiza je pokazala da čestice kao što su $\mathrm{Al}_{7} \mathrm{Cu}_{2} \mathrm{Fe}$ i $\mathrm{MgZn}_{2}$ imaju važnu ulogu u točkastoj koroziji te su se nakon sačmarenja smanjili broj $\mathrm{i}$ veličina pukotina na površini.

Ključne riječi: aluminijska legura; hrapavost; otpornost na koroziju; sačmarenje; točkasta korozija; zaostala naprezanja

\section{Introduction}

Surfaces of machine components can be improved by hardening technique, such as laser and shot peening, which increases fatigue strength and fatigue resistance.

Shot Peening (SP) provides kinetic energy of hard particles which induces compressive residual stresses, which contribute to an increase in surface carrying capacity under dynamic loading. Material behaviour after treatment can be additionally estimated by fracture mechanics testing. A weak point of mechanical processes of surface hardening such as SP is that the surface treated will be rough and its corrosion resistance will reduce [1].

The effect of SP of machine components depends on numerous parameters, which produces changes in surface topography, microstructure, in variations of hardness and residual stresses and are frequently complemented by dynamic tests.

Herzog et al. [2] described the SP process and optimum parameters, which ensure surface-layer properties chosen in advance. They proved that a distribution of compression residual stresses could not be presented clearly by Almen intensity alone; it is necessary to include also other parameters influencing the residualstress variation. The process is frequently used in practical applications due to its practicality and simplicity since it is performed at ambient temperature; therefore, residual-stress variations are easier to manage and they have less determined variation.

Mhaede [3] studied the effects of various process parameters of shot peening and ball-burnishing on the surface layer properties, i.e. surface roughness, microhardness and residual compressive stresses, fatigue and corrosion fatigue properties of Al-alloy AA7075 T73. The results show pronounced enhancement in the fatigue life tested in ambient air as well as corrosion fatigue life tested in 3,5\% $\mathrm{NaCl}$ after both shot peening (SP) and ball-burnishing (BB) compared to the electrolytically polished (EP) reference conditions.

Trdan et al. [4] examined the effect of laser shock peening without coating (LSPwC) on the corrosion behaviour of AA6082-T651 alloy in a near natural chloride environment. The results confirmed LSPwC as an effective method, yielding lower anodic dissolution $\left(E_{\mathrm{sw}}-E_{\mathrm{corr}}\right)$, improved repassivation $\left(E_{\mathrm{corr}}-E_{\mathrm{rp}}\right)$ as well as corrosion current reduction. It was found that LSPwC reduces crystallographic and surface-hemispherical pitting, as well as intergranular attack.

In the study the results reported by Pariona et al. [5] reveal the formation of weld filet structures with metastable phases and finely dispersed precipitates. The creation of a finely porous layer of protective coating produced during the rapid remelting process contributed to increase the corrosion resistance of laser-treated specimens when compared with untreated specimens. The results indicated an anodic shift of open-circuit potential $\left(\mathrm{E}_{\mathrm{OCP}}\right)$ after laser surface melting due to the formation of aluminium oxide in the treated area.

Abdulstaar et al [6] examined corrosion behaviour of ultrafine-grained (UFG) commercial pure aluminium $\mathrm{Al}$ 1050 processed by rotary swaging (RS) using potentiodynamic polarization and weight loss immersion test in $3,5 \% \mathrm{NaCl}$ solution. Corrosion behaviour of UFG Al 1050 was compared with that of coarse grained (CG) 
as-received material. The results showed that ultrafine grain refinement by RS led to marked improvement of the corrosion resistance. The improvement in corrosion resistance is profited from the denser and stable passive film due to more grain boundaries, larger fraction of nonequilibrium grain boundaries and residual stress of the UFG pure aluminium.

Gao [7] studied the fatigue strength for $1 \times 10^{7}$ cycles of 7050-T7451 aluminium alloy for machined, laserpeened, and shot-peened specimens. Moreover, fatigue lives were compared under the same load conditions. Results show that the laser peening induces a deeper compressive residual stress layer and better surface finish, therefore, it improves fatigue properties more effectively. Fractographic examination and analysis shows that the fatigue cracks initiate in the subsurface layer beneath the compressive residual stress field for laser- and shotpeened specimens, whereas the fatigue cracks form at surface for as-machined ones.

\section{Experimental procedure \\ 2.1 Base materia}

Alloy designated as ENAW 7075 was in temper state T651; the solution was heat treated, stress relieved by stretching a controlled amount (permanent set 1,5 to $3 \%$ ) and then artificially aged. The products receive no further straightening after stretching. The heat treatment process was conducted with homogenization annealing at a temperature of $475{ }^{\circ} \mathrm{C}$, followed by quenching and artificial ageing at a temperature of $130{ }^{\circ} \mathrm{C}$ for 12 hours. The chemical composition of the alloy and its mechanical properties are given in Tab. 1 and Tab. 2 .

Table 1 Chemical composition of the treated aluminium alloy ENAW 7075 T651

\begin{tabular}{|c|c|c|c|c|c|c|c|c|}
\hline $\begin{array}{c}\text { Chemical } \\
\text { composition } \\
/ \mathrm{wt} \%\end{array}$ & $\mathrm{Si}$ & $\mathrm{Mg}$ & $\mathrm{Cu}$ & $\mathrm{Mn}$ & $\mathrm{Fe}$ & $\mathrm{Cr}$ & $\mathrm{Zn}$ & $\mathrm{Ti}$ \\
\hline ENAW 7075 & 0,12 & 2,36 & 1,58 & 0,05 & 0,17 & 0,19 & 5,70 & 0,03 \\
\hline
\end{tabular}

Table 2 Mechanical properties of the treated aluminium alloy ENAW 7075 T651

\begin{tabular}{|c|c|c|c|c|}
\hline \multirow{2}{*}{ Designation } & \multicolumn{4}{|c|}{ Mechanical properties } \\
\cline { 2 - 5 } & $R_{\mathrm{m}} / \mathrm{MPa}$ & $R_{\mathrm{p} 0.2} / \mathrm{MPa}$ & $\mathrm{A} / \%$ & $\mathrm{HV}_{0.1}$ \\
\hline ENAW 7075 & 625 & 575 & 11 & 155 \\
\hline
\end{tabular}

Specimens were cut from a rolled plate with a thickness of $10 \mathrm{~mm}$ where cutting was performed with a machine cutter for the preparation of specimens for a metallographic examination. The specimens were cut carefully to avoid the overheating of surface and thus the undesirable microstructural changes and introduction of additional residual stresses into the surface.

\subsection{Heat treatments}

Flat specimens were first subjected to homogenization annealing at a temperature of $465{ }^{\circ} \mathrm{C}$ for 2 hours and after that the quenching in water was followed to ambient temperature. Specimens were artificially aged at two different temperatures, i.e. $170{ }^{\circ} \mathrm{C}$ and $195{ }^{\circ} \mathrm{C}$ for 8 hours with the objective of obtaining different numbers and sizes of precipitates. The ageing process was concluded by taking the specimens from the furnace and leaving them outside to cool down to ambient temperature.

\subsection{Shot peening}

SP-treated surface extends the life cycle of a machine component under the same load. Therefore, the effects of individual treatment parameters need to be known, such as the selection shot types, kinetic energy of shots (intensity) and the coverage of individual sphere traces on the surface.

Shot peening was performed using spherically conditioned S170 steel spheres with an average size of a diameter $430 \mu \mathrm{m}$ and a hardness value of $56 \mathrm{HRC}$. Different states of aluminium alloy 7075 were treated with Almen intensities of $4 \mathrm{~A}$ and $8 \mathrm{~A}$, while the degree of coverage was set to $200 \%$.

Coverage is defined as ratio of the dimpled surface to the total surface after shot peening. Complete coverage of a shot peened surface is crucial in performing high quality shot peening. Coverage is the measure of original surface area that has been obliterated by shotpeening dimples. Coverage should never be less than $100 \%$ as fatigue and stress corrosion cracks can develop in the unpeened area that is not encased in residual compressive stress.

If coverage is specified as greater than $100 \%$ (i.e. $150 \%, 200 \%$ ) this means that the processing time to achieve $100 \%$ has been increased by that factor. A coverage of $200 \%$ time would have twice the shot peening exposure time as $100 \%$ coverage.

\section{Results and discussion 3.1 Surface roughness}

Surface roughness was determined in all specimens immediately after they were cut and after the surfaces were treated by shot peening. Surface roughness was measured in various directions according to cutting direction. The specimens were also measured for microhardness and residual stresses before and after treatment.

Standard DIN 4761 describes a shotpeened surface (SP) as a flat surface. Characteristics of the shot-peened specimens chosen for roughness evaluation are mean arithmetic roughness $R a$ and mean roughness depth $R z$.

The arithmetic mean roughness $R a$ of the surface profile and the mean roughness depth $R z$ were chosen as the properties used to estimate the roughness of shotpeened specimens. In their studies, authors generally focus only on one of these when describing surface profile. In our research, however, both values were calculated in order to achieve a better view of the surface arch formation. The values $(R a$ and $R z)$ were determined based on the captured surface profile utilizing Taylor Hobson's Surtronic 3+ profile meter and their software, TalyProfileLite 3.1.4.

The profiles of the shot-peened specimen surfaces were captured at a length of $L=8 \mathrm{~mm}$, with 10 repetitions, and recorded at different reference points, namely, in two directions at the specimen edge and in the specimen centre. The measuring positions and surface profile directions are indicated in Fig. 1. 


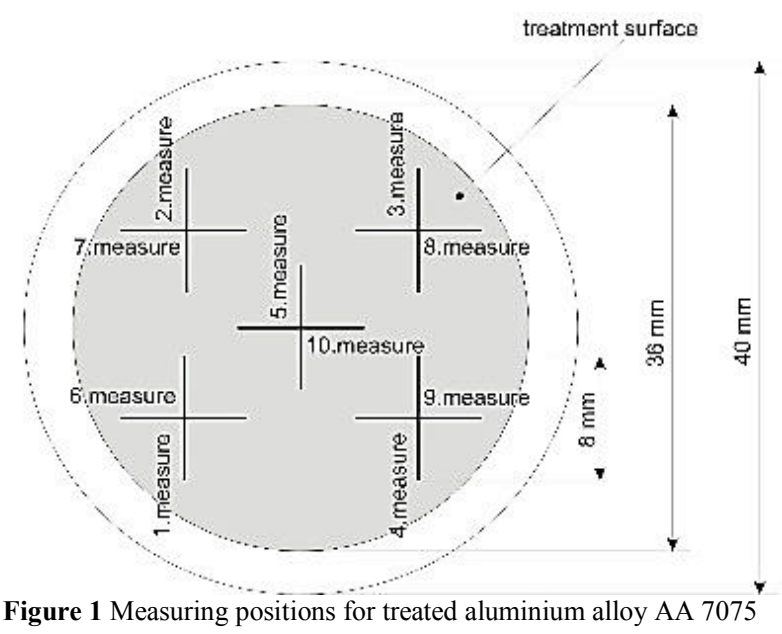

After the surface was treated by shot peening using hard steel balls, its profile varied based on treatment conditions. The calculated values confirm this fact. The column diagrams representing the calculated arithmetic mean of surface roughness $R a$ and the mean values of profile depth $R z$ are shown in Fig. 2. The calculated values of both properties, $R a$ and $R z$ differentiate on the multiple level before as well as after specimen treatment.

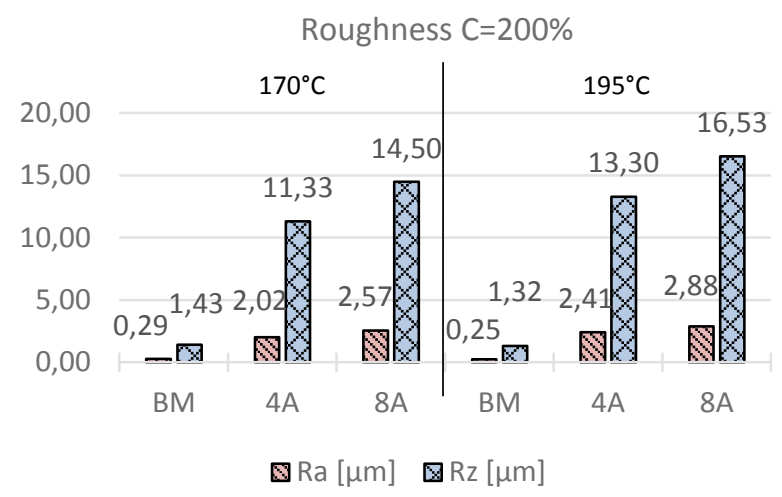

Figure 2 Surface roughness after treatment for treated aluminium alloy AA 7075

The specimens treated with different Almen intensity confirm that the particles' kinetic energy used for the shot peening treatment of the surface is greater and, with constant mass flow, contributes to increasing surface roughness profile. Surface roughness can be estimated based on the arch height and given in Almen intensity. The results reveal that roughness increased with an increase in Almen intensity and with higher ageing temperature, i.e. $195{ }^{\circ} \mathrm{C}$. An increase in roughness of the shot-peened surfaces is characteristic of softer materials, including the selected aluminium alloy aged at temperature $195^{\circ} \mathrm{C}$.

\subsection{Residual stresses}

Residual stresses were measured using a relaxation blind hole-drilling method in accordance with ASTM E 837-01E standard [8]. For that a Vishay RS-200 drilling device with a pneumatic turbine for achieving high drilling speeds and a CEA-06-062-UM measuring rosette were used [9]. The residual stress variation in treated and untreated specimens was determined using an integral method and an $\mathrm{H}$-drill program package. The integral method provides a separate evaluation of residual stress at each increment of depth. Thus, its spatial resolution is the highest of all the methods and is the method of choice when measuring rapidly varying residual stresses, such as shot peening.

As-machined specimens showed residual stresses in the thin surface layer amounting to around $-50 \mathrm{MPa}$, induced most probably due to the specimen preparation. Relatively small-magnitude measured stress of the asmachined specimens was neglected in further evaluation.

Fig. 3 shows a comparison of the minimum principal residual stress profiles for the specimens aged at temperature $170{ }^{\circ} \mathrm{C}$. The coverage was set to $200 \%$ and two different Almen intensities of $4 \mathrm{~A}$ and $8 \mathrm{~A}$ were chosen. From the residual stress variation it can be inferred that the values of the minimum residual stresses in the specimens at the near surface amount to around $100 \mathrm{MPa}$ at $4 \mathrm{~A}$ and around $-140 \mathrm{MPa}$ at $8 \mathrm{~A}$. The minimum principal compressive residual stresses of the SP treated specimen with 4A reaches to a value of -195 $\mathrm{MPa}$ at a depth of $250 \mu \mathrm{m}$ and then slowly turns towards the surface. The specimen treated with $8 \mathrm{~A}$ Almen intensity shows almost the same gradient as the previous one, where the residual stresses from the near surface go down to a value of $-215 \mathrm{MPa}$ at the same depth as one treated with Almen intensity 4A and then turns more steeply towards the surface where it reaches $-80 \mathrm{MPa}$ at $1000 \mu \mathrm{m}$.

Fig. 4 shows a distribution of main residual stress variations in a specimen at aging temperature $195{ }^{\circ} \mathrm{C}$, treated with the Almen intensities of $4 \mathrm{~A}$ and $8 \mathrm{~A}$. The differences were observed in the depth of hardening and in the value of compressive residual stresses. In a specimen treated with the intensity of $4 \mathrm{~A}$ at a depth of $220 \mu \mathrm{m}$, the maximum obtained value of compressive residual stress was $-177 \mathrm{MPa}$. After reaching the maximum value of the residual stress, the values rapidly rise to amount of $-98 \mathrm{MPa}$ at depth $550 \mu \mathrm{m}$ and then remain almost constant to the greater depths. In a specimen treated with the Almen intensity of $8 \mathrm{~A}$, compressive residual stresses increased more steeply throughout the hardened layer and in the depth of $280 \mu \mathrm{m}$ reaches their maximum value of $-190 \mathrm{MPa}$ and then slowly rises towards the surface. Differences in residual stress values in greater depths were minimal, and amounted to only $10 \mathrm{MPa}$.

However, regardless of any shot peening parameters, the compressive residual stresses in the specimens are after reaching maximal value directed towards the tensile area, but all retain compressive nature at depth $1000 \mu \mathrm{m}$. It can be stated that higher ageing temperatures result in smaller residual stress values.

The comparison of the ageing conditions shows residual stress profiles are related to the growth, density and size of precipitates, resulting from the ageing of aluminium alloy. 


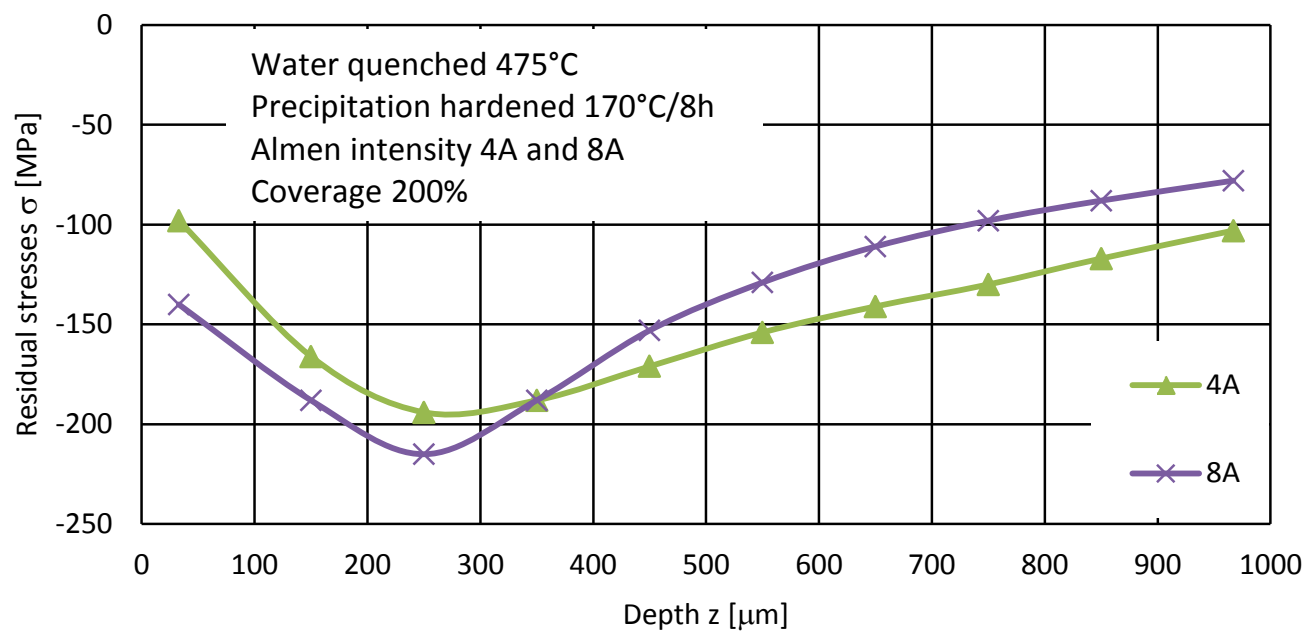

Figure 3 Residual stress profiles after shot peening of aluminium alloy 7075 with different Almen intensity.

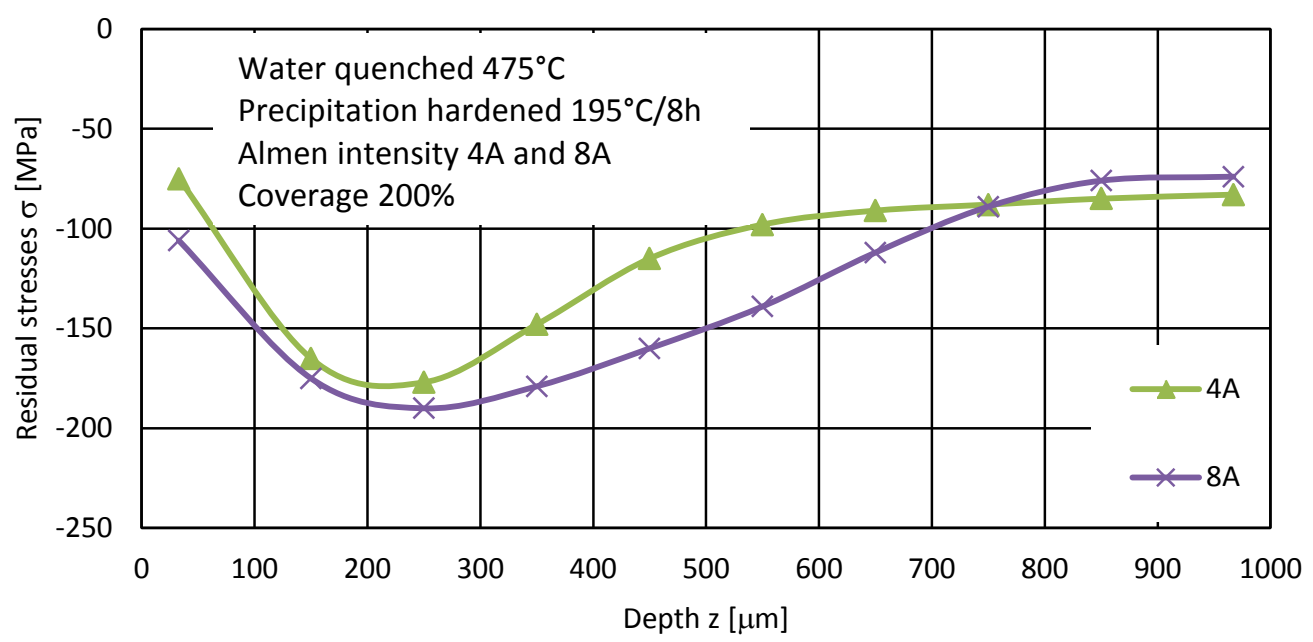

Figure 4 Residual stress profiles after shot peening of aluminium alloy 7075 with different Almen intensity.

\subsection{Pitting corrosion - cyclic polarisation scans}

The corrosion behaviour was investigated in $0,15 \mathrm{M}$ $\mathrm{NaCl}$ solution, made from deionised water at $\mathrm{pH}$ value 6,7 . The temperature of the test medium was equal in all experiments, i.e. $22^{\circ} \mathrm{C}$.

Electrochemical characteristics were evaluated by cyclic polarization using the potentiostatVoltaLab PGZ100 and the CNC glass cell according to ASTM standards. Measurements were recorded using a software package VoltaMaster 4 by Radiometer Analytical. The curves were plotted in semi-logarithmic scale for a better interpretation of the measured data and electrochemical characteristics that have been calculated using Tafel extrapolation method.

Cyclic polarisations (CP) were performed by using an initial delay time at the equilibrium state of $90 \mathrm{~min}$ in order to stabilize the surface at open potential polarization. A polarisation scan was carried out in the anodic direction at a scanning rate of $1 \mathrm{mV} / \mathrm{s}$, starting at $100 \mathrm{mV} / \mathrm{SCE}$ more negative than open-circuit potential (OCP). The sweep direction was reversed at a limited threshold value of $1 \mathrm{~mA} / \mathrm{cm}^{2}$.

Fig. 5 shows the results of an EDS analysis of the untreated sample. The heterogeneous microstructures of heat-treatable $\mathrm{Al}$ alloys such as 7XXX render them highly susceptible to corrosion [10].

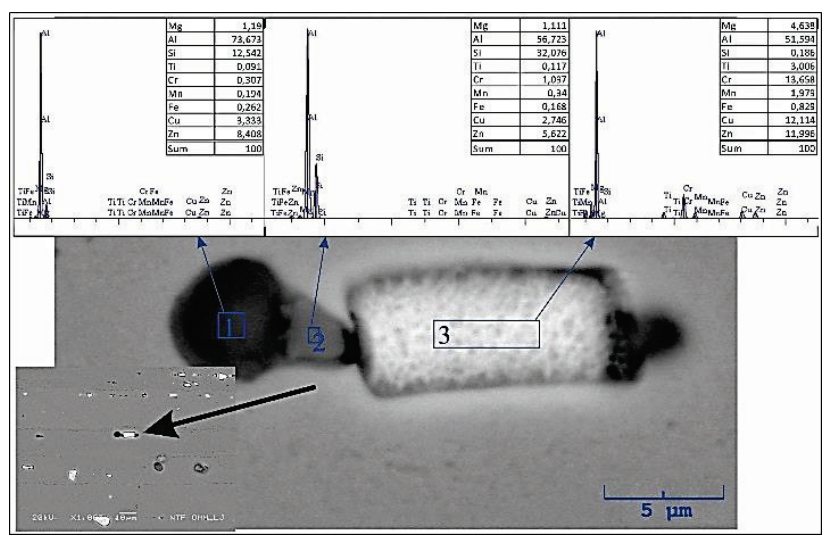

Figure 5 SEM image and the EDS spectrum results of some precipitates in aluminium alloy

It is known that $\mathrm{Cu}$ particles and $\mathrm{Cu}$-containing intermetallics present on $\mathrm{Al}$ surface can promote pitting corrosion at adjacent sites. In contrast, in the case of $\mathrm{AA7075}$, it was reported that the presence of such intermetallics as $\mathrm{Al}_{7} \mathrm{Cu}_{2} \mathrm{Fe}$ and $(\mathrm{Al}, \mathrm{Cu})_{6}(\mathrm{Fe}, \mathrm{Cu})$, and such 
strengthening particles as $\mathrm{MgZn}_{2}$ play an important role in pitting corrosion and stress corrosion cracking [11].

It can be seen that three types of intermetallics are present in solution heat-treated AA7075: $\mathrm{Al}_{7} \mathrm{Cu}_{2} \mathrm{Fe}$, $(\mathrm{Al}, \mathrm{Cu})_{6}(\mathrm{Fe}, \mathrm{Cu})$ and $\mathrm{Mg}_{2} \mathrm{Si}$. All types of intermetallics have irregular shapes and are present in bands aligned along the rolling direction. The $\mathrm{Al}_{7} \mathrm{Cu}_{2} \mathrm{Fe}$ and the
$(\mathrm{Al}, \mathrm{Cu})_{6}(\mathrm{Fe}, \mathrm{Cu})$ intermetallics are the most abundant, while the $\mathrm{Mg}_{2} \mathrm{Si}$ intermetallics are present in small quantities. The morphology, the size, and the composition of the intermetallics are the same for all solution heattreated AA7075 alloys in our case. Therefore, they are not affected by solution heat treatment performed on AA7075-T6.

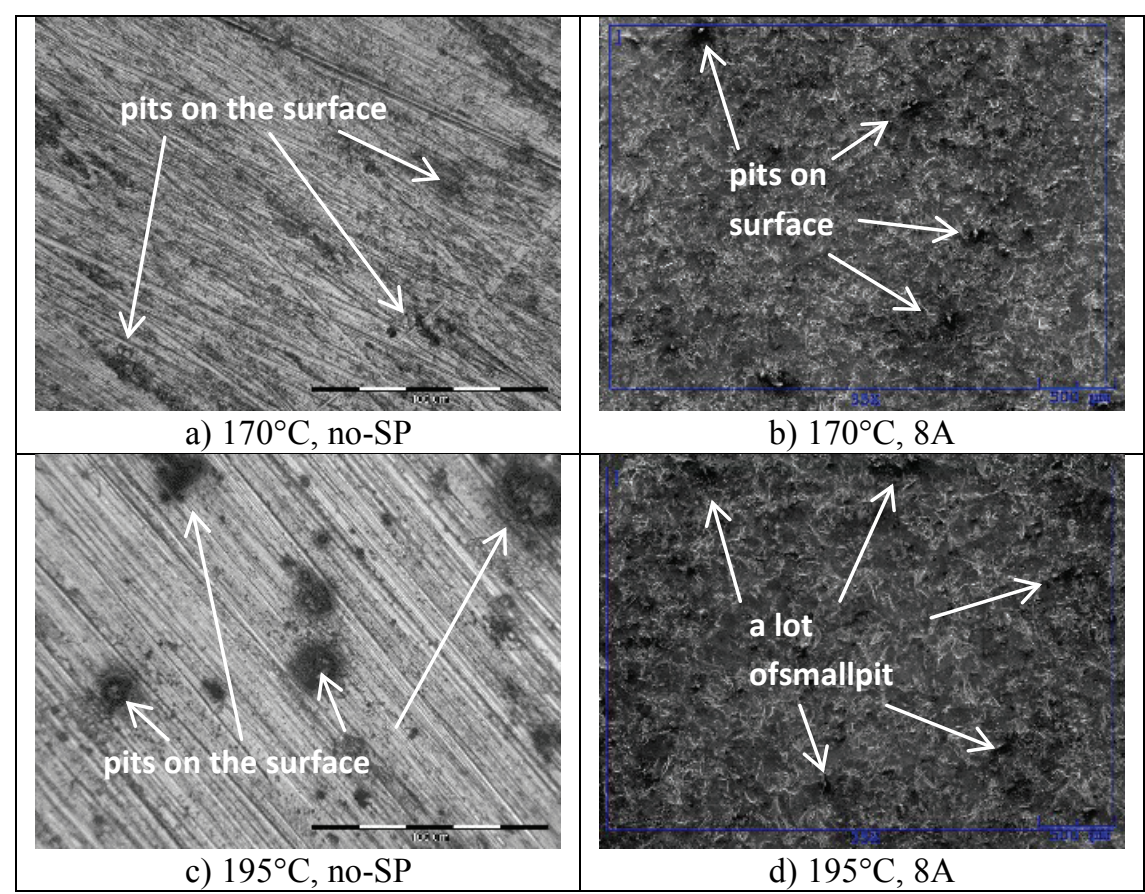

Figure 6 Surface morphology of the specimens after $\mathrm{CP}$ corrosion test.

Fig. 6 shows the surface conditions of both untreated and SP-treated specimens after cyclic polarisation measurements. After examination of the untreated specimen after the $\mathrm{CP}$ test (Fig. 6a and 6c), it was observed that small and large pits prevail over the entire surface.

However, with SP treated specimens (Fig. 6b and 6d), the surface morphology of the aluminium alloy is quite different from the previous one: the size of the pits in aged specimens at temperatures $170{ }^{\circ} \mathrm{C}$ and $195{ }^{\circ} \mathrm{C}$ is reduced, but the number stays quite the same. It seems that the corrosion attack in the SP treated specimen was mainly confined to isolated regions that may be areas of non-homogeneity, such as SP affected dimples, untreated regions or metallic particles remaining from SP media. As research shows, in almost all dimples in SP treated surface appear occurrence of pitting corrosion.

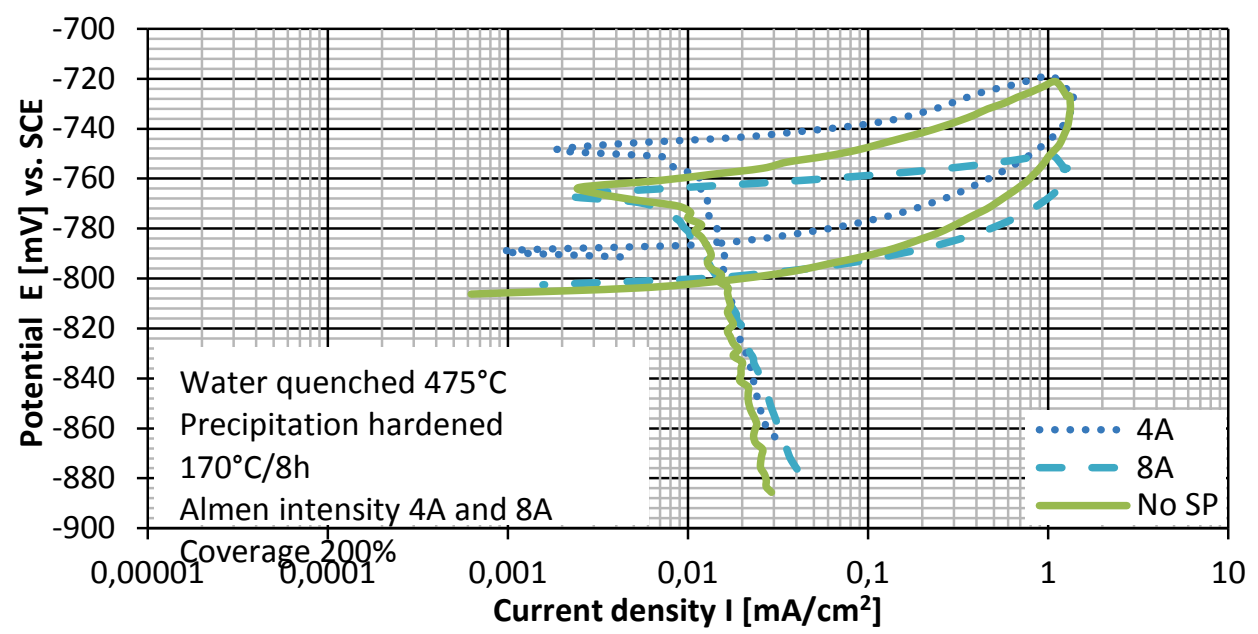

Figure7 Cyclic polarisation curves of SP treated and untreated specimens at ageing temperature $170{ }^{\circ} \mathrm{C}$.

Fig. 7 shows the cyclic polarisation curves for the aluminium alloy at the ageing temperature of $170{ }^{\circ} \mathrm{C}$ measured before and after SP with two different intensities, $4 \mathrm{~A}$ and $8 \mathrm{~A}$. The results show that the specimen treated with an intensity of $4 \mathrm{~A}$ has a slightly lower free corrosion potential $E_{\text {corr }}$ value of $-748 \mathrm{mV}_{\mathrm{SCE}}$ than the specimen treated with an intensity of $8 \mathrm{~A}$ with its 
value of $-768 \mathrm{mV}_{\mathrm{SCE}}$, which is very similar to untreated specimen.

A comparison of the corrosion current densities $I_{\text {corr }}$ was performed with a Tafel analysis. The specimen treated with an intensity of $4 \mathrm{~A}$ had a corrosion current density value of $9,3452 \mu \mathrm{A} / \mathrm{cm}^{2}$, which was 1,2 times lower than the specimen treated with an intensity of $8 \mathrm{~A}$, whose $I_{\text {corr }}$ value was $10,7140 \mu \mathrm{A} / \mathrm{cm}^{2}$. However the corrosion rate of specimen treated with intensity $4 \mathrm{~A}$ and then $8 \mathrm{~A}$ increased due to surface roughness, i.e. 101,5 $\mu \mathrm{m} / \mathrm{Y}$ and $116,1 \mu \mathrm{m} / \mathrm{Y}$, respectively, but they are still lower than untreated specimen with corrosion rate $C R=$ $146,4 \mu \mathrm{m} / \mathrm{Y}$.

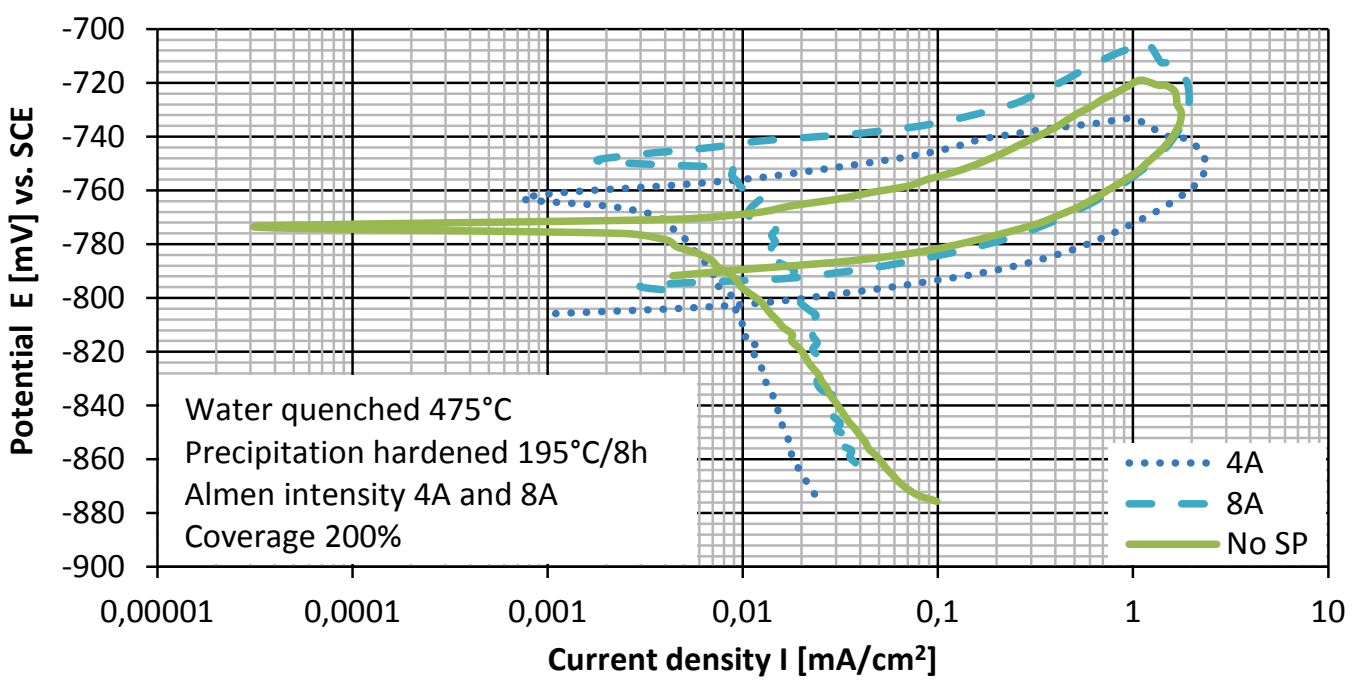

Figure 8 Cyclic polarisation curves of SP treated and untreated specimens at ageing temperature $195{ }^{\circ} \mathrm{C}$.

Fig. 8 shows the cyclic polarisation curves for aluminium alloy after SP at ageing temperatures $195^{\circ} \mathrm{C}$ and the same Almen intensities as before, i.e. 4A and 8A.

The Tafel extrapolation method, which was used to extrapolate corrosion potential $E_{\text {corr }}$ and corrosion current density $I_{\text {corr }}$, showed a significantly lower corrosion current of specimen treated with intensity $4 \mathrm{~A}$ compared to the specimen treated with $8 \mathrm{~A}$. The latter showed a corrosion current density of $11,6129 \mu \mathrm{A} / \mathrm{cm}^{2}$ and a corrosion potential of $-750 \mathrm{mV}_{\mathrm{SCE}}$ compared to intensity $4 \mathrm{~A}$ with its values of $I_{\text {corr }}=5,7352 \mu \mathrm{A} / \mathrm{cm}^{2}$ and $E_{\text {corr }}=$ $-762 \mathrm{mV}_{\mathrm{SCE}}$. The corrosion current reduced for almost two times.

The most anodic behaviour of $E_{\text {corr }}$ is achieved with specimen at Almen intensity $8 \mathrm{~A}$, indicating the important role of roughness after SP treatment. The most cathodic $E_{\text {corr }}$ behaviour was seen in the untreated specimen, showing an $E_{\text {corr }}$ reduction of $25 \mathrm{mV}_{\mathrm{SCE}}$ in comparison with the specimen at intensity $8 \mathrm{~A}$.

The results of the cyclic polarizations confirmed that the SP specimen compared to the untreated specimen exhibited more expressive partial passivation, whereas the potential $E_{\mathrm{sw}}$ at which the potential reached a limited threshold value of $1 \mathrm{~mA} / \mathrm{cm}^{2}$.

The corrosion rate (in $\mu \mathrm{m} /$ year) was evaluated from the corrosion current density according to Faraday's law [12]:

$C . R .=3,27 \times 10^{-3} \cdot \frac{M \cdot w t .}{n} \cdot \frac{1}{\rho} \cdot I_{\text {corr }}\left[\frac{\mu \mathrm{m}}{\mathrm{Y}}\right]$,

where the factor $3,27 \times 10^{-3}$ includes the Faraday constant, and the metric and time conversion factors. For the aluminium alloy, M.wt. is the molar mass $(26,98$ $\mathrm{g} / \mathrm{mol}$ ), $\mathrm{n}$ is the valence (3), $\rho$ is the density of the corroding metal $\left(2,7 \mathrm{~g} / \mathrm{cm}^{3}\right)$, and $I_{\text {corr }}$ is the corrosion current density (in $\mu \mathrm{A} / \mathrm{cm}^{2}$ ) and thus Eq. (1) reduces to:

$C . R .=10,89 \cdot I_{\text {corr }}\left[\frac{\mu \mathrm{m}}{\mathrm{Y}}\right]$.

For the specimens treated with $170{ }^{\circ} \mathrm{C}$ and shot peened with $4 \mathrm{~A}$, the calculated values of the C.R. confirmed a lower value compared to the untreated one, i.e. $101,5 \mu \mathrm{m} / \mathrm{Y}$ and $146,4 \mu \mathrm{m} / \mathrm{Y}$, respectively.

\section{Conclusion}

In order to determine the effects of the SP treatment of specimens made of aluminium alloy AA7075, a great number of experiments were required. The optimization of the shot peening parameters could enable controlled sizes and residual stress profiles.

Also in this paper a study conducted on the corrosion behaviour of AA7075 under different state conditions, immersed in aqueous solutions of $\mathrm{NaCl}$ was performed. To determine the effects of pitting corrosion on the SP treated aluminium alloy AA7075 in different states, a series of tests were performed. The following can be confirmed based on the performed residual stress measurements and cyclic polarization tests:

a) SP induced plastic deformation increased the surface layer hardness and introduced significant levels of residual compressive stresses, which was the highest at Almen intensity of $8 \mathrm{~A}$ and ageing temperature 170 ${ }^{\circ} \mathrm{C}$ amounting to the maximal value of $-215 \mathrm{MPa}$ at the depth of $250 \mu \mathrm{m}$. The increasing of the Almen intensity increases the residual stresses magnitude and penetration depth, while using different media results in the same residual stress profiles as long as the Almen intensity remains constant [3]. 
b) The calculated values of corrosion rate (C.R.) were found to decrease almost gradually with the higher ageing temperature at Almen intensity 4A. The lowest corrosion rate was obtained with the specimen at $4 \mathrm{~A}$ and ageing temperature $195{ }^{\circ} \mathrm{C}(61,8 \mu \mathrm{m} / \mathrm{Y})$ which is almost two times lower compared to the untreated specimen $(114,1 \mu \mathrm{m} / \mathrm{Y})$.

c) The low corrosion resistance after some SP treatment is related to the higher surface roughness after SP that leads to increased real surface area, which in turn increased the active anodic areas in the SP surface.

d) The increase in the corrosion current density indicated a higher pit growth rate. The increased surface roughness of the SP treated specimens and the possible remains of the steel medium at the aluminium surface could have influenced the electrochemical properties, although the treated surface was chemically cleaned. In general, the larger the area of the hysteresis loop, the greater the susceptibility of the material to pitting corrosion.

e) After the shot peening treatment at $200 \%$ coverage, the number of surface pits was reduced. The SP treated specimens outperformed the parent material when exposed to the $0,15 \mathrm{M} \mathrm{NaCl}$ water solution environment by a factor of 2. Other authors have also proposed that the pit sizes were large on the unpeened surfaces whereas they were much smaller on the shot peened surface and also had fewer pits than the unpeened surface. [13]

\section{References}

[1] Schulze, V. Modern Mechanical Surface Treatment: States, Stability, Effects, WILEY-VCH Verlag GmbH \& Co. KGaA, Weinheim, 2006.

[2] Herzog, R.; Zinn, W.; Scholtes, B.; Wohlfahrt, H. The Significance of Almen Intensity for the Generation of Shot Peening Residual Stresses. // Proceedings of the $6^{\text {th }}$ International Conference on Shot Peening / San Francisco, 1996, pp. 270-281.

[3] Mhaede, M. Influence of Surface Treatments on Surface Layer Properties: Fatigue and Corrosion Fatigue Performance of AA7075-T73. // Materials and Design. 41, (2012), pp. 61-66. DOI: 10.1016/j.matdes.2012.04.056

[4] Trdan, U.; Grum, J. SEM/EDS Characterization of Laser Shock Peening Effect on Localized Corrosion of Al Alloy in a Near Natural Chloride Environment. // Corrosion Science. 82, (2014), pp. 328-338. DOI: 10.1016/j.corsci.2014.01.032

[5] Pariona, M. M.; Teleginski, V.; Santos, K. D.; Machado, S.; Zara, A. J.; Zurba, N. K.; Riva, R. Yb-fiber Laser Beam Effects on the Surface Modification of Al-Fe Aerospace Alloy Obtaining Weld Filet Structures: Low Fine Porosity and Corrosion Resistance. // Surface and Coatings Technology. 206, (2012), pp. 2293-2301. DOl: 10.1016/j.surfcoat.2011.10.007

[6] Abdulstaar, M.; Mhaede, M.; Wagner, L.; Wollmann, M. Corrosion Behaviour of Al 1050 Severely Deformed by Rotary Swaging. // Materials and Design. 57, (2014), pp. 325-329. DOI: 10.1016/j.matdes.2014.01.005

[7] Gao, Y. K. Improvement of Fatigue Property in 7050 T7451 Aluminum Alloy by Laser Peening and Shot Peening. // Materials Science and Engineering: A. 528, (2011), pp. 3823-3828. DOI: 10.1016/j.msea.2011.01.077
[8] Standard Test Method for Determining Residual Stresses by the Hole Drilling Strain Gage Method, ASTM E 837-01, 1995, pp. 694-703.

[9] Tech note TN 503-5, Measurement of Residual Stresses by the Hole-Drilling Strain Gage Method, Vishay.

[10] Sankaran, K. K.; Perez, R.; Jata, K. V. Effects of Pitting Corrosion on the Fatigue Behavior of AluminumAlloy 7075-T6:Modeling and Experimental Studies. // Materials Science and Engineering A. 297, (2001), pp. 223-229. DOI: 10.1016/S0921-5093(00)01216-8

[11] Andreatta, F.; Terryn, H.; de Wit, J. H. W. Corrosion Behaviour of Different Tempers of AA7075 Aluminium Alloy. // Electrochimica Acta. 49, (2004), pp. 2851-2862. DOI: 10.1016/j.electacta.2004.01.046

[12] El-TaibHeakal, F.; Tantawy, N. S.; Shehta, O. S. Influence of Chloride Ion Concentration on the Corrosion Behavior of Al-bearing TRIP Steels. // Materials Chemistry and Physics. 130, (2011), pp. 743-749. DOI: 10.1016/j.matchemphys.2011.07.064

[13] Hatamleh, O.; Singh, P. M.; Garmestani, H. Corrosion Susceptibility of Peened Friction Stir Welded 7075 Aluminum Alloy Joints. // Corrosion Science. 51, (2009), pp. 135-143. DOI: 10.1016/j.corsci.2008.09.031

\section{Authors' addresses}

Sebastjan Žagar, BSc, Assistant

Faculty of Mechanical Engineering, University of Ljubljana Aškerčeva 6, 1000 Ljubljana, Slovenia

E-mail: sebastjan.zagar@fs.uni-lj.si

Janez Grum, PhD, Full professor

Faculty of Mechanical Engineering, University of Ljubljana Aškerčeva 6,1000 Ljubljana, Slovenia

E-mail: janez.grum@fs.uni-lj.si 